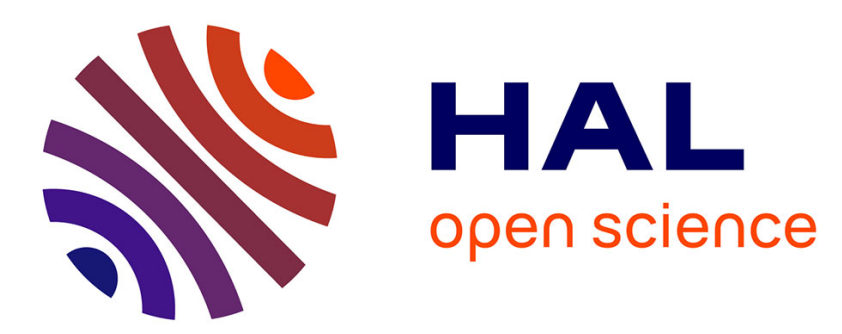

\title{
3-Fluoro-4-hexylthiophene as a Building Block for Tuning the Electronic Properties of Conjugated Polythiophenes
}

Frédéric Gohier, Pierre Frère, Jean Roncali

\section{- To cite this version:}

Frédéric Gohier, Pierre Frère, Jean Roncali. 3-Fluoro-4-hexylthiophene as a Building Block for Tuning the Electronic Properties of Conjugated Polythiophenes. Journal of Organic Chemistry, 2013, 78 (4), pp.1497-1503. 10.1021/jo302571u . hal-03344585

\section{HAL Id: hal-03344585 \\ https://univ-angers.hal.science/hal-03344585}

Submitted on 15 Sep 2021

HAL is a multi-disciplinary open access archive for the deposit and dissemination of scientific research documents, whether they are published or not. The documents may come from teaching and research institutions in France or abroad, or from public or private research centers.
L'archive ouverte pluridisciplinaire HAL, est destinée au dépôt et à la diffusion de documents scientifiques de niveau recherche, publiés ou non, émanant des établissements d'enseignement et de recherche français ou étrangers, des laboratoires publics ou privés. 


\title{
3-Fluoro-4-hexylthiophene as a Building Block for Tuning the Electronic Properties of Conjugated Polythiophenes
}

\author{
Frédéric Gohier, Pierre Frère,* and Jean Roncali \\ LUNAM Université, University of Angers, MOLTECH-Anjou UMR CNRS 6200, SCL Group, 2 boulevard Lavoisier, Angers, France
}

Supporting Information

ABSTRACT: 3-Fluoro-4-hexylthiophene has been prepared by a synthetic route involving perbromination of 3-hexylthiophene followed by protection of the 2- and 5-positions of thiophene by trimethylsilyl groups and bromine/fluorine exchange. As expected, 3-hexyl-4-fluorothiophene oxidizes at a higher potential than 3-hexylthiophene; however, all attempts to electropolymerize this new thiophenic monomer have remained unsuccessful. Three terthienyls containing 3-hexylthiophene, 3-fluoro-4-hexylthiophene, and 3-bromo-4-hexylthiophene as the median group have been synthesized and used as substrates for electropolymerization. The electronic properties of the starting terthienyls and the resulting polymers have been analyzed by cyclic voltammetry and UV-vis spectroscopy, and the effects of substitution of the median thiophene ring are discussed.

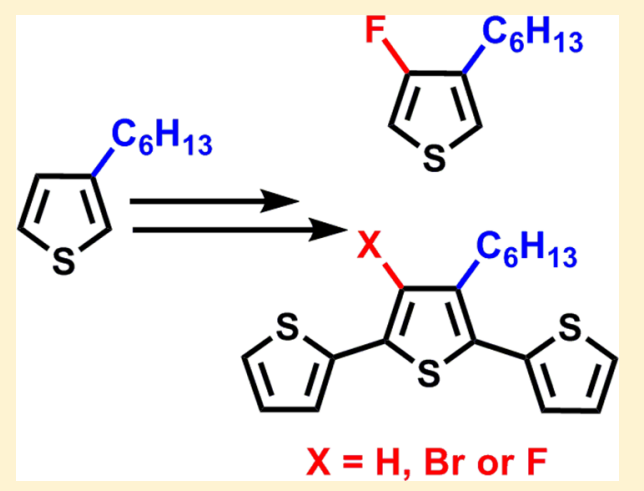

\section{INTRODUCTION}

The control of the band gap of conjugated polymers has been subject to intensive research efforts aiming at the development of optimized donor materials for donor-acceptor bulk heterojunction solar cells. ${ }^{1}$ The band gap of $\pi$-conjugated systems can be controlled through different synthetic approaches, including rigidification of the conjugated backbone, quinoidization, or realization of alternating donor (D) and acceptor (A) groups or synergistic combinations of these various approaches. ${ }^{2}$

While the quest for materials showing metallic character and intrinsic conductivity has been a major motivation for gap reduction, ${ }^{3}$ the recent emergence of organic photovoltaics (OPV) at the forefront of research on $\pi$-conjugated systems has provided a new impetus to the field. ${ }^{4,5}$ However, the design of active materials for OPV has also imposed specific prerequisites on the electronic properties of conjugated systems, and in this regard the smallest gap is no longer the best since, in addition to a relatively reduced band gap $(1.40-1.50 \mathrm{eV}$ seems to be the optimum), ${ }^{6}$ a precise control of the energy levels of the valence and conduction band of the final material and hence of the HOMO and LUMO levels of the basic individual molecules or polymer chains is required to produce donor-acceptor heterojunction cells with optimal photon/electron conversion efficiency. ${ }^{2,6,7}$

Poly(3-hexylthiophene) (P3HT) has been widely investigated as a donor material in OPV cells, and bulk heterojunction solar cells based on $\mathrm{P} 3 \mathrm{HT}$ have reached power conversion efficiencies in the range of $5-6 \% .{ }^{8}$ However, these values are lower than the efficiencies of the best cells based on $\mathrm{D}-\mathrm{A}$ low band gap conjugated polymers that have reached values exceeding $8.0 \%$. In comparison to D-A low band gap copolymers, $\mathrm{P} 3 \mathrm{HT}$ presents the advantage of a homogeneous structure based on a single repeating basic unit and hence of a more straightforward synthesis. However, the band gap of P3HT $(\sim 1.90 \mathrm{eV})$ leads to insufficient coverage of the solar irradiation spectrum and hence limits the efficiency of the resulting OPV cells.

A possible solution to this problem would involve the introduction of an electron acceptor group at the 4-position of P3HT, but this approach has been scarcely developed. For example, poly(3cyano-4-hexyl)thiophene, synthesized by direct bromination of regioregular P3HT followed by substitution of the bromine atoms by cyano groups, has been described, but a band gap of $2.5 \mathrm{eV}$ is reported. ${ }^{10} \mathrm{In}$ fact, this approach is subject to stringent steric restrictions that drastically limit the size of the possible candidate withdrawing substituents. Indeed, bulky withdrawing substituents induce distortions in the conjugated backbone that compensate or annihilate the expected gap reduction by electronic effects. ${ }^{11}$ In this context, the fluorine atom with a van der Waals radius of $1.35 \AA$ and a Pauling electronegativity of 4.0 is the smallest electron-withdrawing group. ${ }^{12}$ The introduction of fluorine atoms is expected to stabilize the HOMO and LUMO energy levels and thus to help the stability toward oxidative degradation. ${ }^{5,13}$ Introduction of fluorine atoms on the acceptor part of D-A polymers has recently been realized to give materials reaching PCE up to $7 \%$ in bulk heterojunction solar cells. ${ }^{14}$

As a further step in our approach of developing D/A conjugated polymers with $\mathrm{D}$ and $\mathrm{A}$ groups on the same thiophene unit, ${ }^{15,16}$ we report here the synthesis of 3-fluoro-4-hexylthiophene (1) and the effects of the fluorine atoms on the electronic properties of polythiophenes are discussed on the basis of a comparative analysis of the electronic properties of the polymers obtained by electropolymerization of terthienyls 3T-H, 3T-F, and 3T-Br (Chart 1).

Received: November 24, 2012

Published: January 23, 2013 


\section{Chart 1}
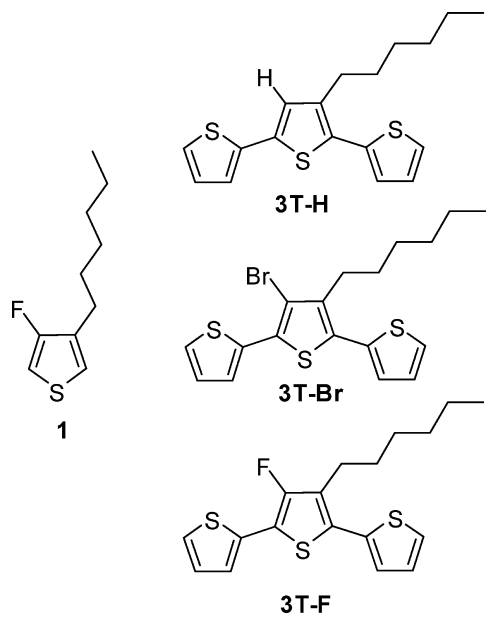

\section{RESULTS AND DISCUSSION}

Synthesis. The synthetic routes explored for the synthesis of $\mathbf{1}$ are shown in Scheme 1. First we tried to prepare 3-fluoro4-hexylthiophene (1) from 3-bromo-4-hexylthiophene (2) by direct bromine-fluorine exchange. After perbromination of 3-hexylthiophene 3 by bromine in acetic acid to give 1,2,5tribromo-3-hexylthiophene (4), ${ }^{17,18}$ the bromine atoms at the 2 - and 5-positions were selectively removed by the sequence butyllithium-water to give 3-bromo-4-hexylthiophene (2) in quantitative yield. Although the synthesis of the fluorinated derivative 1 by direct fluorination of the 3-lithiated thiophene derivative was described in a patent, ${ }^{19}$ numerous attempts remained unsuccessful and afforded miscellaneous products. Proton and fluorine NMRs showed the formation of several unidentified compounds but also the insertion of fluorine atom in the $\alpha$-position of the thiophene. The stability of the 3-lithiated thiophene is low above $-78{ }^{\circ} \mathrm{C}$, leading to a migration of lithium atoms to the $\alpha$-position of thiophene. ${ }^{20}$ Therefore, in order to avoid the formation of byproducts, the 2- and 5-positions were blocked by trimethylsilyl groups in compound 5 , easily obtained in $88 \%$ yield by trapping the dilithiated intermediates of $\mathbf{4}$ by chlorotrimethylsilane. $^{21,22}$ Then bromine-lithium exchange with $n$-butyllithium followed by reaction with $\left(\mathrm{PhSO}_{2}\right)_{2} \mathrm{NF}$ proceeded smoothly to afford 6 in moderate yield. ${ }^{21}$ The silyl groups were removed with tetrabutylammonium fluoride to give 1 in $67 \%$ yield. ${ }^{19,23}$

The synthesis of the terthiophenes depicted in Scheme 2 was based on a 2 -fold Stille coupling. Thus, the coupling between 2,5-dibromothiophene 7 and a slight excess of 2-(tributylstannyl)thiophene (8) yielded terthiophene $3 \mathbf{T}-\mathbf{H}$ in $95 \%$ yield. ${ }^{24}$ The silyl groups of 6 can be easily replaced by bromine atoms by treatment with bromine at room temperature to give 2,5-dibromo-3-fluoro-4-hexylthiophene (9) in 95\% yield. ${ }^{23}$ Attempts to obtain 3T-F by a direct coupling between 8 and 9 led to a mixture of 3T-F and bithiophene, which are difficult to separate. Indeed, due to the low reactivity of the dibromo compound 9, homocoupling of the stannic derivative gave bithiophene as the major product. A second route toward 3T-F starting from 3T-Br, in which the fluorination step took place after the Stille coupling, has been explored (Scheme 2). A Stille cross-coupling reaction between tribromo derivative 4 and the stannic reagent 8 proceeded regioselectively at $40{ }^{\circ} \mathrm{C}$ to give terthiophene $3 \mathrm{~T}-\mathrm{Br}$ in $73 \%$ yield. Only a small amount of compound $10(<5 \%)$ corresponding to the tris coupling was detected. It can be noted that when the temperature was raised to $80{ }^{\circ} \mathrm{C}$, the tetrathiophene 10 was isolated in $81 \%$ yield.

As in the case of compound 1 , clean bromine-fluorine exchange requires the protection of the terminal $\alpha$-positions with trimethylsilyl groups. A simplified procedure has been used for the preparation of terthiophene 11. As trimethylsilyl chloride does not react with $\mathrm{LDA}$ at $-78^{\circ} \mathrm{C}$, it can be present when the base is added on the terthiophene 3T-Br. The formed dilithiated derivative is trapped immediately with TMSCl to give terthiophene $\mathbf{1 1}$ in 73\% yield. Then bromine of terthiophene $\mathbf{1 1}$ was exchanged with lithium by treatment with $n$-BuLi at low temperature and then by fluorine using $\left(\mathrm{PhSO}_{2}\right)_{2} \mathrm{NF}$ to give $\mathbf{1 2}$ in $58 \%$ yield. The target compound 3T-F was finally obtained in $68 \%$ yield as a pale yellow liquid after removal of silyl groups with TBAF. All new compounds were fully characterized.

Electronic Properties. The CV traces of 1 and 3-hexylthiophene (3) present an irreversible oxidation wave with an anodic peak potential $E_{\mathrm{pa}}$ increasing from $2.22 \mathrm{~V}$ for 3 to $2.37 \mathrm{~V}$ for $\mathbf{1}$ upon replacement of hydrogen by the more electronegative fluorine atom (Figure S1, Supporting Information). Although successive potential scan to a solution of 3-hexylthiophene (3) leads to the classical growth of a polymer film on the electrode, all attempts to electropolymerize $\mathbf{1}$ with various concentrations of monomer, solvents, electrolytes, or temperatures remained unsuccessful.

The single occupied molecular orbital (SOMO) of the cation radicals of $1^{\bullet+}$ presents a strong dissymmetry, showing that the $\alpha$-position next to the fluorine atom is deactivated, preventing the coupling reactions involved in the polymerization process. ${ }^{16}$

Taking into account these negative results and in order to obtain some information on the effect of fluorine on the electronic properties of more extended thiophenic conjugated systems,

Scheme 1. Synthesis of 3-Fluoro-4-hexylthiophene $(1)^{a}$

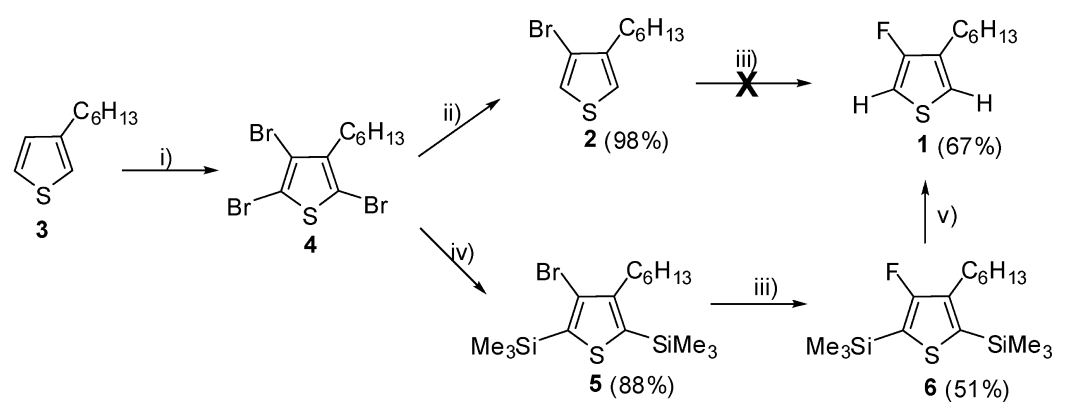

${ }^{a}$ Reagents and conditions: (i) $\mathrm{Br}_{2}$, acetic acid, $60^{\circ} \mathrm{C}$; (ii) $n$-BuLi, THF, $-78^{\circ} \mathrm{C}$ then $\mathrm{H}_{2} \mathrm{O}$; (iii) $n$-BuLi, THF, $-78{ }^{\circ} \mathrm{C}$ then $(\mathrm{PhSO})_{2} \mathrm{NF}$; (iv) $n$ - $\mathrm{BuLi}$, THF, $-78{ }^{\circ} \mathrm{C}$ then TMSCl; (v) TBAF, $\mathrm{CH}_{2} \mathrm{Cl}_{2}$, room temperature. 
Scheme 2. Syntheses of Terthiophenes 3T-H, 3T-Br, and 3T-F

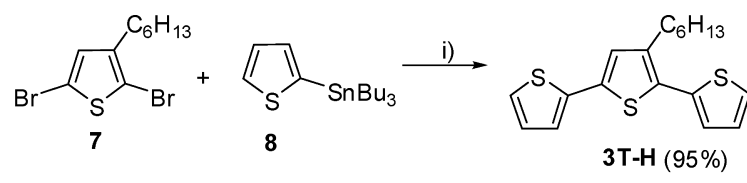

6

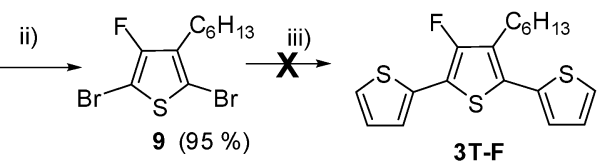

4

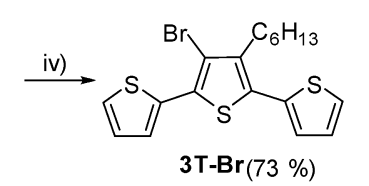<smiles>c1ccc(-c2c(-c3cccs3)sc(-c3cccs3)c2-c2cccs2)cc1</smiles>

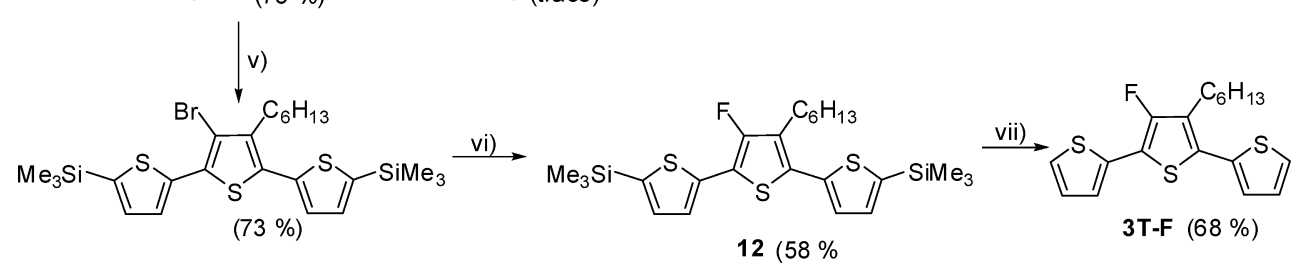

${ }^{a}$ Reagents and conditions: (i) $\mathrm{Pd}\left(\mathrm{PPh}_{3}\right)_{4}, \mathrm{DMF}, 80^{\circ} \mathrm{C}$; (ii) $\mathrm{Br}_{2}, \mathrm{CH}_{2} \mathrm{Cl}_{2}$, room temperature; (iii) 8 (excess), $\mathrm{Pd}\left(\mathrm{PPh}_{3}\right)_{4}, \mathrm{DMF}$, room temperature or $40{ }^{\circ} \mathrm{C}$; (iv) 8 (excess), $\mathrm{Pd}\left(\mathrm{PPh}_{3}\right)_{4}, \mathrm{DMF}, 40{ }^{\circ} \mathrm{C}$; (v) LDA, TMSCl, THF, $-78{ }^{\circ} \mathrm{C}$; (vi) $n$-BuLi, THF, $-78{ }^{\circ} \mathrm{C}$ then $(\mathrm{PhSO})_{2} \mathrm{NF}$; (vii) TBAF, $\mathrm{CH}_{2} \mathrm{Cl}_{2}$, room temperature.
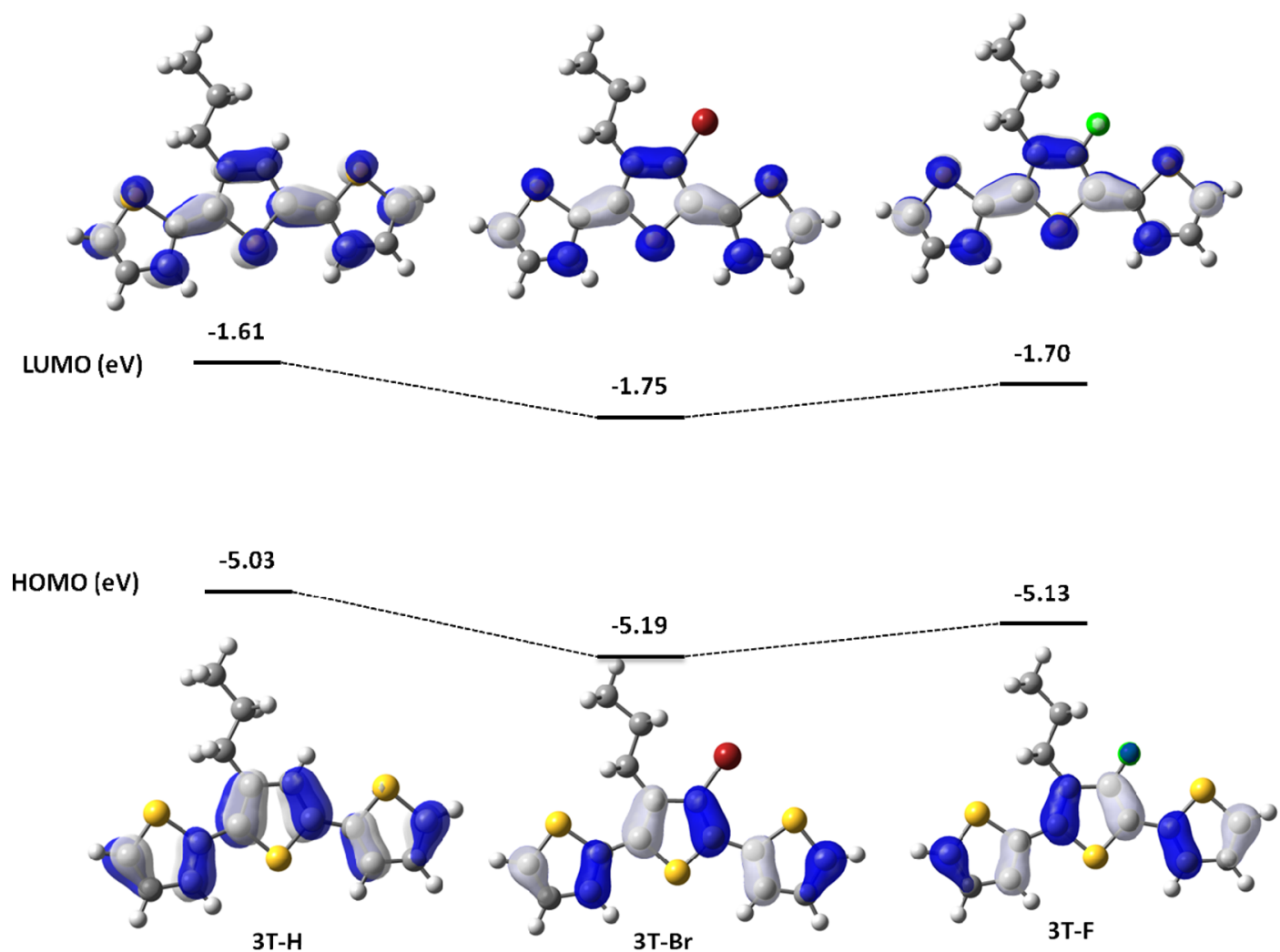

Figure 1. Calculated HOMOs and LUMOs and energy levels for 3T-X $(\mathrm{X}=\mathrm{H}, \mathrm{Br}$ or $\mathrm{F})$.

we have carried out a comparative analysis of the electronic properties of trimers 3T-X $(\mathrm{X}=\mathrm{H}, \mathrm{Br}, \mathrm{F})$ using theoretical calculations, UV-vis absorption spectroscopy, and cyclic voltammetry.

Theoretical calculations were performed at the ab initio density functional level with the Gaussian package by using Becke's three-parameter gradient corrected functional (B3LYP) with a polarized $6-31 G(d, p)$ for the HOMO and LUMO level determinations. Hexyl chains were replaced by propyl chains to limit the computational time. The optimized structures of the trimers 3T-X show a fully planar conformation with the thiophene units 
Table 1. HOMO and LUMO Energy Levels and Energy Gap $\Delta E_{\text {th }}$ Calculated by DFT Methods, Experimental Absorption Data, and Cyclic Voltammetric Data of Trimers 3T-X $(X=H, B r, F)$

$\begin{array}{lccccccc}\text { compd } & \mathrm{HOMO}^{a}(\mathrm{eV}) & \mathrm{LUMO}^{a}(\mathrm{eV}) & \Delta E_{\mathrm{th}}{ }^{a}(\mathrm{eV}) & \lambda_{\max }{ }^{b}(\mathrm{~nm}) & \Delta E_{\mathrm{opt}}{ }^{c}(\mathrm{eV}) & E_{\mathrm{pa}}{ }^{d}(\mathrm{~V}) & \mathrm{HOMO}^{e}(\mathrm{eV}) \\ \text { 3T-H } & -5.03 & -1.61 & 3.42 & 345 & 3.10 & 0.98 & -5.69 \\ \text { 3T-Br } & -5.19 & -1.75 & 3.44 & 345 & 3.10 & 1.12 & -5.82 \\ \text { 3T-F } & -5.13 & -1.70 & 3.43 & 350 & 3.06 & 1.08 & -5.78\end{array}$

${ }^{a} \mathrm{~B} 3 \mathrm{LYP} / 6.31 \mathrm{G}(\mathrm{d}, \mathrm{p}) .{ }^{b}$ Conditions: $10^{-4} \mathrm{M}$ in $\mathrm{CH}_{2} \mathrm{Cl}_{2} \cdot{ }^{c} \mathrm{Optical}$ band gap calculated from the edge of the absorption band. ${ }^{d}$ Conditions: $5 \times 10^{-4} \mathrm{M}$ in $0.1 \mathrm{M} \mathrm{Bu}_{4} \mathrm{NPF}_{6} / \mathrm{CH}_{3} \mathrm{CN}$, scan rate $100 \mathrm{mV} \mathrm{s}{ }^{-1}$, vs SCE. ${ }^{e}$ Calculated from $E_{\mathrm{HOMO}}=-E_{\text {ox,onset }}-5.1 .^{27}$
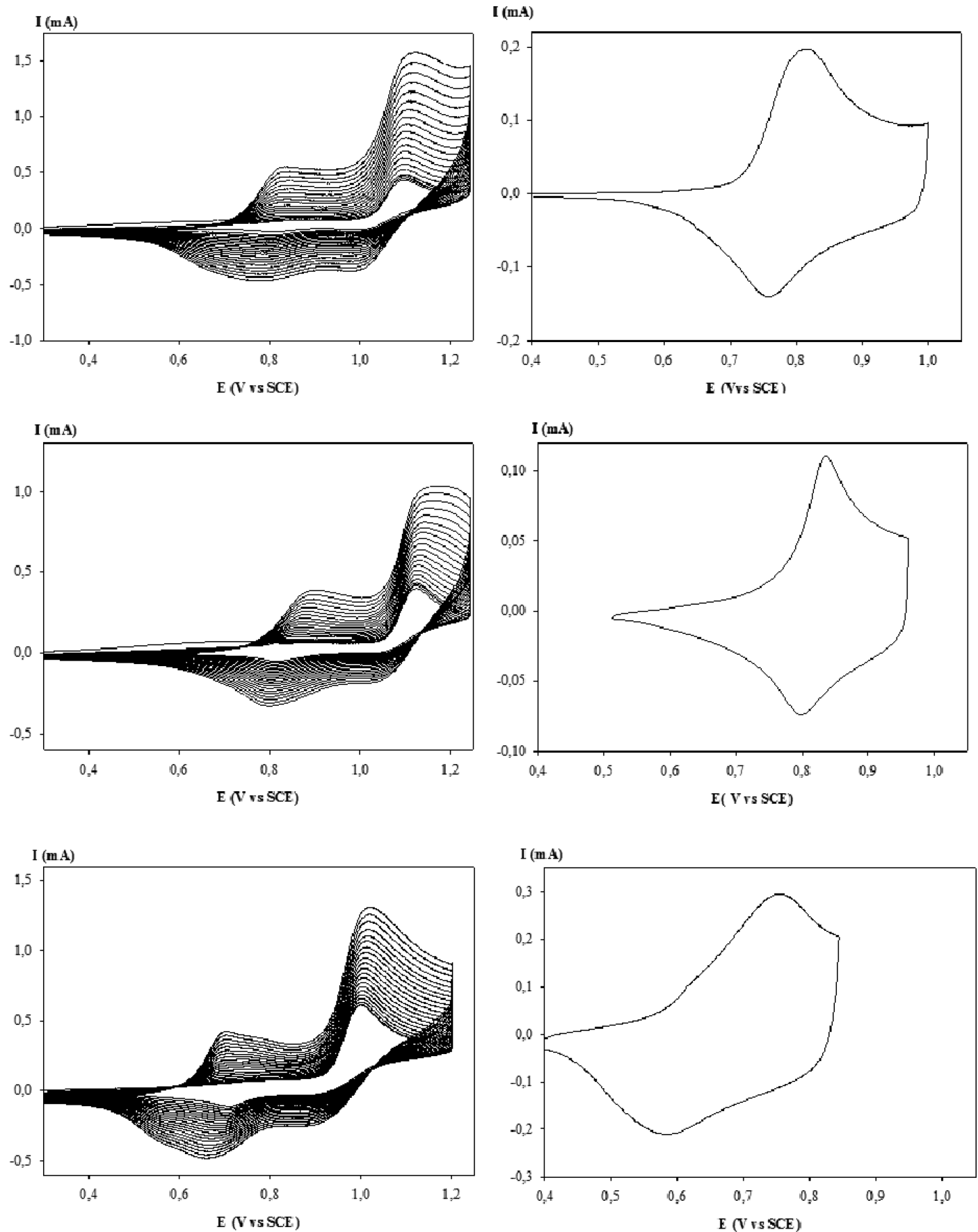

Figure 2. (left) Electropolymerization of $3 \mathrm{~T}-\mathrm{F}$ (top), $3 \mathrm{~T}-\mathrm{Br}$ (middle), and $3 \mathrm{~T}-\mathrm{H}$ (bottom) at $5 \times 10^{-3} \mathrm{M}$ in $0.10 \mathrm{M} \mathrm{Bu}_{4 \mathrm{~N}} \mathrm{PF}_{6} / \mathrm{CH}_{3} \mathrm{CN}$, reference SCE, $v=50 \mathrm{mV} \mathrm{s}^{-1}$. (right) $\mathrm{CV}$ of the resulting electrodeposited materials poly(3T-F) (top), poly(3T-Br) (middle), and poly(3T-F) (bottom) in $0.10 \mathrm{M}$ $\mathrm{Bu}_{4} \mathrm{NPF}_{6} / \mathrm{CH}_{3} \mathrm{CN}$, reference SCE, $v=50 \mathrm{mV} \mathrm{s}^{-1}$.

in a $\delta$-trans conformation (Figure 1). Replacement of hydrogen by the bulky bromine atom does not provoke any torsion of the molecule. The short intramolecular Br- - $-S$ distance $\left(d_{\mathrm{Br}-\mathrm{-S}}=\right.$ $3.20 \AA$ ), inferior to the sum of the van der Waals radii of sulfur 
and bromine $(3.65 \AA)$, is an indication of a possible intramolecular interaction which stabilizes the planar geometry. In the planar conformation observed for bithiophenes bearing only one bromine atom, it has been indicated that $\mathrm{Br}-\mathrm{-}-\mathrm{S}$ intramolecular interactions could contribute to self-rigidify the conjugated system. ${ }^{25}$ A planar conjugated backbone has also been reported for oligomers based on the 3,4-difluorothiophene building block. ${ }^{21}$ Examination of the electron density of molecular orbitals shows that, for the three terthiophenes, the HOMO and LUMO are delocalized over the whole conjugated system. The calculated HOMO and LUMO levels and the gap of 3T-X show a moderate effect of the halogen atoms (Table 1). Thus, the replacement of hydrogen by fluorine in 3T-F stabilizes the HOMO and LUMO levels by about $0.10 \mathrm{eV}$. For 3T-Br the bromine atom produces a slight decrease $(\sim 0.05 \mathrm{eV})$ of the HOMO and LUMO levels in comparison to 3T-F. For both the HOMO and LUMO, the electron density on the halogen atoms is relatively low. However, the density on fluorine is larger than on bromine, suggesting a stronger mesomeric donor effect of fluorine. The larger positive mesomeric effect of fluorine $\left(\sigma_{\mathrm{R}}=\right.$ $-0.34)$ in comparison to bromine $\left(\sigma_{\mathrm{R}}=-0.16\right)^{26}$ could explain the small destabilization of the HOMO and LUMO levels observed for 3T-F.

The UV-vis absorption spectra (Figure S2, Supporting Information) show that the three compounds present similar absorption maxima $\left(\lambda_{\max }\right)$ with, however, a small bathochromic shift of $\lambda_{\max }$ for 3T-F.

The CV traces of the trimers 3T-X (Figures S3-S5, Supporting Information) show an irreversible oxidation peak at $0.98 \mathrm{~V}$ for $3 \mathrm{~T}-\mathrm{H}$, while a ca. $100 \mathrm{mV}$ positive shift is observed for 3T-Br and 3T-F, reflecting the electron-withdrawing effect of halogen substituents.

Electropolymerization. The terthiophenes 3T-X have been electropolymerized (Figure 2), and the electronic properties of the resulting polymers, named poly $(3 \mathrm{~T}-\mathrm{X})$, have been studied (Table 2). Application of recurrent potential scans to acetonitrile

Table 2. Cyclic Voltammetry ${ }^{a}$ and UV-Vis Absorption Data ${ }^{b}$ for $\operatorname{poly}(3 \mathrm{~T}-\mathrm{X})(\mathrm{X}=\mathrm{H}, \mathrm{Br}, \mathrm{F})$

\begin{tabular}{|cccc|}
\hline polymer & $E_{\mathrm{pa}}(\mathrm{V})$ & $\lambda_{\max }(\mathrm{nm})$ & $E_{\mathrm{g}}^{c}(\mathrm{eV})$ \\
\hline poly(3T-F) & 0.82 & 479 & 1.87 \\
poly(3T-Br $)$ & 0.83 & 485 & 1.89 \\
poly(3T-H) & 0.75 & 478 & 1.99
\end{tabular}

${ }^{a}$ Polymer film deposited on Pt disk $(d=1 \mathrm{~mm}) \mathrm{CV}$ recorded in $0.10 \mathrm{M}$ $\mathrm{Bu}_{4} \mathrm{NPF}_{6} / \mathrm{CH}_{3} \mathrm{CN}$. ${ }^{b}$ Polymer film deposited on ITO and electrochemically undoped. ${ }^{c}$ Calculated from the foot of the absorption band.

solutions of 3T-X leads to the progressive emergence of a new redox system at lower potential associated with the electrodeposition of a polymer. The CV of the polymers recorded in a monomer-free electrolytic medium presents a broad reversible oxidation wave corresponding to the p-doping of the conjugated backbone, with $E_{\mathrm{pa}}$ increasing from $0.75 \mathrm{~V}$ for $\operatorname{poly}(3 \mathrm{~T}-\mathrm{H})$ to $0.83 \mathrm{~V}$ for poly $(3 \mathrm{~T}-\mathrm{Br})$. These $E_{\mathrm{pa}}$ values are clearly correlated with those of the starting trimers, indicating that the halogen atoms exert similar electron-withdrawing effects on the formation of the radical cation for the precursor and on the polaron state of the resulting polymer. As expected, only a small difference is observed between conjugated systems bearing fluorine and bromine atoms.

The optical properties of the polymers have been analyzed on thin films electrodeposited on indium tin oxide (ITO) electrodes.
The spectrum of the neutral poly $(3 \mathrm{~T}-\mathrm{H})$ presents a $\lambda_{\max }$ value at $478 \mathrm{~nm}$ and a band gap of $1.99 \mathrm{eV}$. Replacement of the hydrogen by halogen atoms leads to a slight decrease of the band gap (ca. $0.10 \mathrm{eV}$ ). As shown in Figure 3 for poly(3T-F), the application of positive

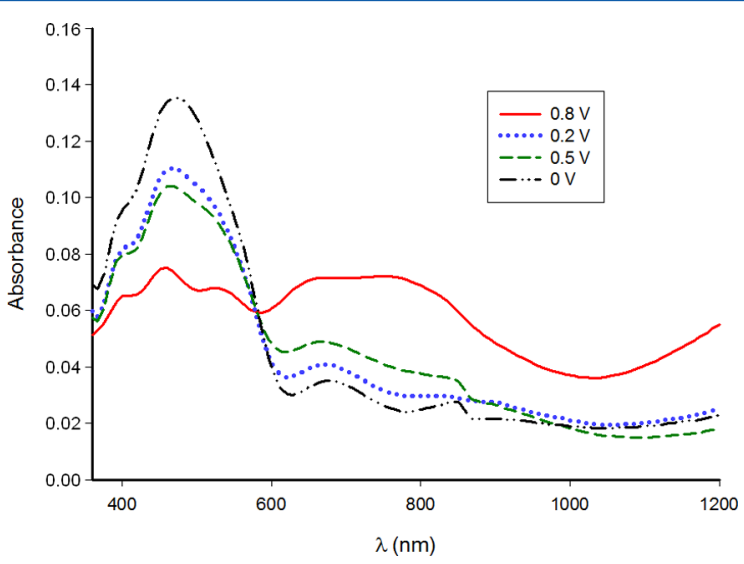

Figure 3. UV-vis absorption spectra of a thin film of poly(3T-F) on ITO at various applied potentials.

potentials produces a decrease in the intensity of the band corresponding to the neutral state and the emergence of a broad band around $800 \mathrm{~nm}$ which could be attributed to the polaron state.

\section{CONCLUSION}

3-Fluoro-4-hexylthiophene has been synthesized from 3-hexylthiophene by fluorine-bromine exchange reactions performed on a thiophene derivative protected at the terminal positions by trimethylsilyl groups. The fluorine atom at the $\beta$-position of the thiophene ring seems to inhibit the electropolymerization, presumably because of the deactivating effect of the fluorine atom. In contrast, terthiophenes containing a central 3-halogeno-4-hexylthiophene undergo straightforward electropolymerization similarly to their nonhalogenated analogues. Theoretical, spectroscopic, and electrochemical data show that the halogen atoms exert a small influence on the electronic properties of the terthiophenes and of the corresponding polymers. The electron-withdrawing effect of the halogen atom stabilizes the HOMO and thus leads to an increase of the oxidation potentials of the terthiophenes and polymers. However, for fluorine, the negative inductive effect is counterbalanced by a positive mesomeric effect. On the other hand, the larger steric hindrance of the bromine atom is limited by S- - - Br intramolecular interactions that stabilize the planarity of the conjugated backbone. On the whole, the two halogen atoms have rather similar effects on the electronic properties of the conjugated system, with a slightly lower gap for the fluoro compounds and slightly higher oxidation potential for the bromo compounds.

\section{EXPERIMENTAL SECTION}

${ }^{1} \mathrm{H}$ and ${ }^{19} \mathrm{~F}$ NMR spectra were obtained at $300.1 \mathrm{MHz}$, and ${ }^{13} \mathrm{C}$ spectra were obtained at $75.7 \mathrm{MHz}$. The spectra were referenced against the internal NMR solvent standard. Chemical shifts are expressed in parts per million (ppm) and are reported as s (singlet), $\mathrm{d}$ (doublet), $\mathrm{t}$ (triplet), $\mathrm{td}$ (doublet triplet), and $\mathrm{m}$ (multiplet); coupling constants $J$ are given in $\mathrm{Hz}$.

Cyclic voltammetry was carried out using a platinum disk as the working electrode, platinum wire as the counter electrode, and saturated calomel as the reference electrode.

2,3,5-Tribromo-4-hexylthiophene (4) was prepared from 3-hexylthiophene by treatment with bromine as described in literature. ${ }^{18}$ 
3-Bromo-4-hexyl-2,5-bis(trimethylsilyl)thiophene (5). 4 (2.94 g, $7.26 \mathrm{mmol})$ was dissolved in THF $(25 \mathrm{~mL})$, and the solution was cooled to $-78{ }^{\circ} \mathrm{C}$. A solution of butyllithium $(1.6 \mathrm{M}$ in cyclohexane, 2 equiv, $9.0 \mathrm{~mL}$ ) was dropped in slowly, and the solution was stirred for $15 \mathrm{~min}$. Chlorotrimethylsilane $(2.2 \mathrm{~mL}, 17.5 \mathrm{mmol})$ was slowly added, and the solution was stirred overnight with warming to room temperature. After addition of water, the phases were separated and the aqueous phase was extracted with $\mathrm{Et}_{2} \mathrm{O}(2 \times 20 \mathrm{~mL})$. The organic phases were dried over $\mathrm{MgSO}_{4}$ and then evaporated under vacuum. The crude product was chromatographed with petroleum ether as eluent to afford a light yellow oil in $88 \%$ yield $(2.50 \mathrm{~g}) .{ }^{1} \mathrm{H}$ NMR $\left(\mathrm{CDCl}_{3}\right): 2.66(\mathrm{t}, 2 \mathrm{H}, J=7.7 \mathrm{~Hz})$; $1.53(\mathrm{~m}, 2 \mathrm{H}) ; 1.34(\mathrm{~m}, 6 \mathrm{H}) ; 0.91(\mathrm{~m}, 3 \mathrm{H}) ; 0.39(\mathrm{~s}, 9 \mathrm{H}) ; 0.34(\mathrm{~s}, 9 \mathrm{H})$ ppm. ${ }^{13} \mathrm{C}$ NMR $\left(\mathrm{CDCl}_{3}\right): 150.1 ; 139.2 ; 138.3 ; 121.7 ; 31.6 ; 31.1 ; 30.9$; $29.8 ; 22.7 ; 14.1 ; 0.1 ;-0.8 \mathrm{ppm}$. Anal. Calcd for $\mathrm{C}_{16} \mathrm{H}_{31} \mathrm{BrSSi}_{2}$ : C, 49.08; H,7.98. Found: C, 48.73; H, 7.67.

3-Fluoro-4-hexyl-2,5-bis(trimethylsilyl)thiophene (6). 5 (0.37 g, $0.94 \mathrm{mmol})$ was dissolved in THF $(5 \mathrm{~mL})$, and the solution was cooled to $-78^{\circ} \mathrm{C}$. A solution of butyllithium (1.6 $\mathrm{M}$ in cyclohexane, 1.1 equiv, $0.64 \mathrm{~mL}$ ) was dropped in slowly, and the solution was stirred for $20 \mathrm{~min}$. A solution of $\mathrm{N}$-fluorobenzenesulfonimide $(0.439 \mathrm{~g}, 1.39 \mathrm{mmol})$ in THF $(3 \mathrm{~mL})$ was slowly added, and the solution was stirred for $2 \mathrm{~h}$ at $-78^{\circ} \mathrm{C}$ and then stirred overnight with warming to room temperature. After addition of water, the organic phase was separated and the aqueous phase was extracted with $\mathrm{Et}_{2} \mathrm{O}(2 \times 20 \mathrm{~mL})$. The organic phases were dried over $\mathrm{MgSO}_{4}$ and then evaporated under vacuum. The crude product was chromatographed with petroleum ether as eluent to afford a light yellow oil in $51 \%$ yield $(0.16 \mathrm{~g}) .{ }^{1} \mathrm{H} \mathrm{NMR}\left(\mathrm{CDCl}_{3}\right): 2.54(\mathrm{t}, 2 \mathrm{H}, \mathrm{J}=$ $8.0 \mathrm{~Hz}) ; 1.53(\mathrm{~m}, 2 \mathrm{H}) ; 1.34(\mathrm{~m}, 6 \mathrm{H}) ; 0.89(\mathrm{~m}, 3 \mathrm{H}) ; 0.37(\mathrm{~s}, 9 \mathrm{H}) ; 0.31$ (s, 9H) ppm. ${ }^{19} \mathrm{~F} \mathrm{NMR}\left(\mathrm{CDCl}_{3}\right):-124.3 \mathrm{ppm} .{ }^{13} \mathrm{C} \mathrm{NMR}\left(\mathrm{CDCl}_{3}\right)$ : $163.4(\mathrm{~d}, J=262 \mathrm{~Hz}) ; 139.1(\mathrm{~d}, J=24 \mathrm{~Hz}) ; 138.5(\mathrm{~d}, J=3 \mathrm{~Hz}) ; 119.4(\mathrm{~d}$, $J=30 \mathrm{~Hz}) ; 31.6 ; 30.7 ; 29.6 ; 28.2 ; 22.6 ; 14.1 ;-0.1 ;-0.5$ ppm. Anal. Calcd for $\mathrm{C}_{16} \mathrm{H}_{31} \mathrm{FSSi}_{2}$ : C, 58.12; H,9.45; S, 9.70. Found: C, 57.80; $\mathrm{H}$, 9.37; S, 9.24.

3-Fluoro-4-hexylthiophene (1). $6(0.66 \mathrm{~g}, 2.0 \mathrm{mmol})$ was dissolved in THF $(6 \mathrm{~mL})$, and the solution was cooled to $0{ }^{\circ} \mathrm{C}$. A solution of tetrabutylammonium fluoride (1 M in cyclohexane, 3 equiv, $3 \mathrm{~mL}$ ) was added slowly, and the solution was stirred for $30 \mathrm{~min}$ at room temperature. After addition of water, the phases were separated and the aqueous phase was extracted with dichloromethane $(2 \times 20 \mathrm{~mL})$. The organic phases were dried over $\mathrm{MgSO}_{4}$ and then evaporated under vacuum. The crude product was chromatographed with petroleum ether as eluent to afford a colorless oil in $67 \%$ yield $(0.25 \mathrm{~g}) .{ }^{1} \mathrm{H}$ NMR $\left(\mathrm{CDCl}_{3}\right): 6.82(\mathrm{dd}, 1 \mathrm{H}, J=3.8$ and $J=3.8 \mathrm{~Hz}) ; 6.64(\mathrm{~d}, 1 \mathrm{H}, J=3.8 \mathrm{~Hz})$; $2.52(\mathrm{t}, 2 \mathrm{H}, J=7.7 \mathrm{~Hz}) ; 1.61(\mathrm{~m}, 2 \mathrm{H}) ; 1.32(\mathrm{~m}, 6 \mathrm{H}) ; 0.90(\mathrm{~m}, 3 \mathrm{H}) \mathrm{ppm}$. ${ }^{19} \mathrm{~F} \mathrm{NMR}\left(\mathrm{CDCl}_{3}\right):-134.7 \mathrm{ppm} .{ }^{13} \mathrm{C}$ NMR $\left(\mathrm{CDCl}_{3}\right): 156.9(\mathrm{~d}, J=258$ $\mathrm{Hz}) ; 131.7(\mathrm{~d}, J=23 \mathrm{~Hz}) ; 119.6(\mathrm{~d}, J=8 \mathrm{~Hz}) ; 102.7(\mathrm{~d}, J=21 \mathrm{~Hz}) ; 31.6$; $29.2 ; 28.9 ; 26.8 ; 22.6 ; 14.0$. Anal. Calcd for $\mathrm{C}_{10} \mathrm{H}_{15} \mathrm{FS}$ : C, 64.47; H, 8.12. Found: C, 64.35; H, 8.07.

2,5-Dibromo-3-fluoro-4-hexylthiophene (9). 6 ( $0.10 \mathrm{~g}, 0.3 \mathrm{mmol})$ was dissolved in $\mathrm{CH}_{2} \mathrm{Cl}_{2}(3 \mathrm{~mL})$. To this solution, at $0{ }^{\circ} \mathrm{C}$, was slowly added bromine $(0.03 \mathrm{~mL}, 0.6 \mathrm{mmol})$. The solution was then stirred for $30 \mathrm{~min}$ at room temperature. A saturated thiosulfate solution $(3 \mathrm{~mL})$ was added to reduce nonreacted bromine. The aqueous phase was extracted with $\mathrm{CH}_{2} \mathrm{Cl}_{2}(2 \times 20 \mathrm{~mL})$. The combined organic phases were dried over magnesium sulfate and then evaporated under vacuum. The crude oil was chromatographed with cyclohexane to afford a light yellow oil in $96 \%$ yield $(0.10 \mathrm{~g}) .{ }^{1} \mathrm{H}$ NMR $\left(\mathrm{CDCl}_{3}\right): 2.52(\mathrm{t}, 2 \mathrm{H}, J=7.6 \mathrm{~Hz})$; $1.52(\mathrm{~m}, 2 \mathrm{H}) ; 1.29(\mathrm{~m}, 6 \mathrm{H}) ; 0.89(\mathrm{~m}, 3 \mathrm{H}) ; 0.37(\mathrm{~s}, 9 \mathrm{H}) ; 0.31(\mathrm{~s}, 9 \mathrm{H})$ ppm. ${ }^{19} \mathrm{~F}$ NMR $\left(\mathrm{CDCl}_{3}\right):-126.7 \mathrm{ppm} .{ }^{13} \mathrm{C} \mathrm{NMR}\left(\mathrm{CDCl}_{3}\right): 153.4(\mathrm{~d}$, $J=263 \mathrm{~Hz}) ; 132.2(\mathrm{~d}, J=23 \mathrm{~Hz}) ; 107.3(\mathrm{~d}, J=10 \mathrm{~Hz}) ; 89.3(\mathrm{~d}, J=3 \mathrm{~Hz})$; $31.5 ; 28.7$; 28.5 ; 27.0; 22.5 ; $14.1 \mathrm{ppm}$. Anal. Calcd for $\mathrm{C}_{10} \mathrm{H}_{13} \mathrm{Br}_{2} \mathrm{FS}$ : C, 34.91; H, 3.81. Found: C, 35.12; H, 3.83.

3'-Bromo-4'-hexyl-2,2':5',2"-terthiophene (3T-Br). 4 (0.50 g, $1.23 \mathrm{mmol})$ and tributylstannylthiophene $(8 ; 1.41 \mathrm{~g}, 3.69 \mathrm{mmol})$ were dissolved in dimethylformamide $(2 \mathrm{~mL})$. Argon was bubbled for $10 \mathrm{~min}$ in the solution. Then $\mathrm{Pd}\left(\mathrm{PPh}_{3}\right)_{4}(70 \mathrm{mg}, 0.06 \mathrm{mmol})$ was added and the solution was stirred for one night at $40^{\circ} \mathrm{C}$. A solution of $\mathrm{KF}(1 \mathrm{M}, 2 \mathrm{~mL})$ was added to the mixture, and the solution was stirred for $1 / 2 \mathrm{~h}$. Brine $(3 \mathrm{~mL})$ was added, and the mixture was extracted with ethyl acetate $(3 \times 10 \mathrm{~mL})$. The organic phases were dried over $\mathrm{MgSO}_{4}$ and evaporated.
The crude product was chromatographed with petroleum ether as eluent, and a pale yellow oil was obtained in $73 \%$ yield $(0.37 \mathrm{~g}) .{ }^{1} \mathrm{H}$ NMR $\left(\mathrm{CDCl}_{3}\right): 7.45(\mathrm{dd}, 2 \mathrm{H}, J=3.7$ and $1.2 \mathrm{~Hz}) ; 7.36(\mathrm{~m}, 2 \mathrm{H}) ; 7.15(\mathrm{dd}, 2 \mathrm{H}$, $J=3.7$ and $1.2 \mathrm{~Hz}) ; 7.09(\mathrm{~m}, 2 \mathrm{H}) ; 2.80(\mathrm{t}, 2 \mathrm{H}, J=8.3 \mathrm{~Hz}) ; 1.64(2 \mathrm{H}, \mathrm{m})$; $1.43(\mathrm{~m}, 2 \mathrm{H}) ; 1.34(4 \mathrm{H}, \mathrm{m}) ; 0.91(\mathrm{t}, 3 \mathrm{H}, J=7 \mathrm{~Hz}) \mathrm{ppm} .{ }^{13} \mathrm{C}$ NMR $\left(\mathrm{CDCl}_{3}\right): 139.5 ; 135.1 ; 134.5 ; 130.6 ; 129.3 ; 127.5 ; 127.2 ; 126.7 ; 126.4$; $126.1 ; 126.0 ; 111.8 ; 31.5 ; 29.6 ; 29.5 ; 29.3 ; 22.6 ; 14.1 \mathrm{ppm}$. Anal. Calcd for $\mathrm{C}_{18} \mathrm{H}_{19} \mathrm{BrS}_{3}$ : C, 52.55; H, 4.65. Found: C, $52.42 ; \mathrm{H}, 4.69$.

(3'-Bromo-4'-hexyl-[2,2':5',2'-terthiophene]-5,5"'-diyl)bis(trimethylsilane) (11). 3T-Br $(1.0 \mathrm{~g}, 2.43 \mathrm{mmol})$ and chlorotrimethylsilane were dissolved in THF $(8 \mathrm{~mL})$, and the solution was cooled to $-78{ }^{\circ} \mathrm{C}$. A solution of lithium diisopropylamide (prepared from BuLi $(2.5 \mathrm{M}, 2.2$ equiv, $2.1 \mathrm{~mL})$ and diisopropylamine $(0.69 \mathrm{~mL}, 2.2$ equiv) in THF $(4 \mathrm{~mL}))$ was added slowly at $-78^{\circ} \mathrm{C}$. The solution was stirred for $1 \mathrm{~h}$ at $-78{ }^{\circ} \mathrm{C}$ and warmed to room temperature overnight. After addition of water, the phases were separated and the aqueous phase was extracted with $\mathrm{Et}_{2} \mathrm{O}(2 \times 20 \mathrm{~mL})$. The organic phases were dried over $\mathrm{MgSO}_{4}$ and then evaporated under vacuum. The crude product was chromatographed with petroleum ether as eluent to afford a light yellow oil in $73 \%$ yield $(0.98 \mathrm{~g}) .{ }^{1} \mathrm{H} \mathrm{NMR}\left(\mathrm{CDCl}_{3}\right): 7.54(\mathrm{~d}, 1 \mathrm{H}, J=3.5 \mathrm{~Hz})$; $7.24(\mathrm{~m}, 3 \mathrm{H}) ; 2.86(\mathrm{t}, 2 \mathrm{H}, J=8.2 \mathrm{~Hz}) ; 1.67(2 \mathrm{H}, \mathrm{m}) ; 1.44(\mathrm{~m}, 6 \mathrm{H}) ; 0.40$ $(\mathrm{t}, 3 \mathrm{H}, J=7.0 \mathrm{~Hz})$ ppm. ${ }^{13} \mathrm{C} \mathrm{NMR}\left(\mathrm{CDCl}_{3}\right): 141.3 ; 141.2 ; 140.3 ; 139.7$; $139.2 ; 134.3 ; 134.0 ; 130.5 ; 129.4 ; 127.6 ; 127.2 ; 111.7 ; 31.4 ; 29.6 ; 29.3$; $29.2 ; 22.6 ; 14.1 ;-0.1$ ppm. HRMS: calcd for $\mathrm{C}_{24} \mathrm{H}_{36} \mathrm{BrS}_{3} \mathrm{Si}_{2}$ 555.0696, found 555.0691 .

(3'-Fluoro-4'-hexyl-[2,2':5',2"-terthiophene]-5,5" -diyl)bis(trimethylsilane) (12). $11(0.68 \mathrm{~g}, 1.22 \mathrm{mmol})$ was dissolved in THF $(3 \mathrm{~mL})$, and the solution was cooled to $-78{ }^{\circ} \mathrm{C}$. A solution of butyllithium ( $1.6 \mathrm{M}$ in cyclohexane, 1.3 equiv, $1.1 \mathrm{~mL}$ ) was dropped in slowly, and the solution was stirred for $20 \mathrm{~min}$. A solution of $N$-fluorobenzenesulfonimide $(0.5 \mathrm{~g}, 1.58 \mathrm{mmol})$ in THF $(2 \mathrm{~mL})$ was slowly added, and the solution was stirred for $2 \mathrm{~h}$ at $-78{ }^{\circ} \mathrm{C}$ and then stirred overnight with warming to room temperature. After addition of water, the organic phase was separated and the aqueous phase was extracted with $\mathrm{Et}_{2} \mathrm{O}(2 \times 20 \mathrm{~mL})$. The organic phases were dried over $\mathrm{MgSO}_{4}$ and then evaporated under vacuum. The crude product was chromatographed with petroleum ether as eluent to afford a light yellow oil in $58 \%$ yield $(0.35 \mathrm{~g}) .{ }^{1} \mathrm{H} \mathrm{NMR}\left(\mathrm{CDCl}_{3}\right): 7.29(\mathrm{~d}, 1 \mathrm{H}, \mathrm{J}=3.5 \mathrm{~Hz})$; $7.20(\mathrm{~m}, 3 \mathrm{H}) ; 2.75(\mathrm{t}, 2 \mathrm{H}, J=7.8 \mathrm{~Hz}) ; 1.65(2 \mathrm{H}, \mathrm{m}) ; 1.36(\mathrm{~m}, 6 \mathrm{H}) ; 0.90$ $(\mathrm{t}, 3 \mathrm{H}, J=7.0 \mathrm{~Hz}) ; 0.36(\mathrm{~s}, 9 \mathrm{H}) ; 0.35(\mathrm{~s}, 9 \mathrm{H}) \mathrm{ppm} .{ }^{19} \mathrm{~F}\left(\mathrm{CDCl}_{3}\right):-127.4$ ppm. ${ }^{13} \mathrm{C}$ NMR $\left(\mathrm{CDCl}_{3}\right): 152.0(\mathrm{~d}, J=263 \mathrm{~Hz}) ; 141.3,140.8(\mathrm{~d}, J=$ $2 \mathrm{~Hz}) ; 140.0(\mathrm{~d}, J=4 \mathrm{~Hz}) ; 137.6(\mathrm{~d}, J=5 \mathrm{~Hz}) ; 134.3(\mathrm{~d}, J=2 \mathrm{~Hz}) ; 128.9$ $(\mathrm{d}, J=22 \mathrm{~Hz}) ; 127.0(\mathrm{~d}, J=8 \mathrm{~Hz}) ; 124.4(\mathrm{~d}, J=3 \mathrm{~Hz}) ; 114.2(\mathrm{~d}, J=15 \mathrm{~Hz})$; $31.5 ; 29.4 ; 29.1 ; 26.2 ; 22.6 ; 14.1,-0.1$ ppm. HRMS: calcd for $\mathrm{C}_{24} \mathrm{H}_{35} \mathrm{FS}_{3} \mathrm{Si}_{2}$ 494.1418, found 494.1413

$3^{\prime}$-Fluoro-4'-hexyl-2,2':5',2'-terthiophene (3T-F). 12 (4.0 g, $8.1 \mathrm{mmol})$ was dissolved in THF $(50 \mathrm{~mL})$, and the solution was cooled to $0{ }^{\circ} \mathrm{C}$. A solution of tetrabutylammonium fluoride $(1 \mathrm{M}$ in cyclohexane, 2.2 equiv, $17.8 \mathrm{~mL}$ ) was dropped in slowly, and the solution was stirred for $30 \mathrm{~min}$ at room temperature. After addition of water $(50 \mathrm{~mL})$ and $\mathrm{CH}_{2} \mathrm{Cl}_{2}$ $(40 \mathrm{~mL})$, the phases were separated and the aqueous phase was extracted with dichloromethane $(2 \times 20 \mathrm{~mL})$. The organic phases were dried over $\mathrm{MgSO}_{4}$ and then evaporated under vacuum. The crude product was chromatographed with petroleum ether as eluent to afford a colorless oil in $68 \%$ yield $(1.93 \mathrm{~g}) .{ }^{1} \mathrm{H}$ NMR $\left(\mathrm{CDCl}_{3}\right): 7.34(\mathrm{dd}, 1 \mathrm{H}, J=$ 5.1 and $J=1.1 \mathrm{~Hz}) ; 7.28(\mathrm{dd}, 1 \mathrm{H}, J=5.1$ and $J=1.1 \mathrm{~Hz}) ; 7.24(\mathrm{dd}, 1 \mathrm{H}$, $J=3.6$ and $J=1.1 \mathrm{~Hz}) ; 7.15(\mathrm{dd}, 1 \mathrm{H}, J=3.6$ and $J=1.1 \mathrm{~Hz}) ; 2.72(\mathrm{t}, 2 \mathrm{H}$, $J=7.8 \mathrm{~Hz}) ; 1.62(\mathrm{~m}, 2 \mathrm{H}) ; 1.32(\mathrm{~m}, 8 \mathrm{H}) ; 0.88(\mathrm{~m}, 3 \mathrm{H}) \mathrm{ppm} .{ }^{19} \mathrm{~F}$ NMR $\left(\mathrm{CDCl}_{3}\right):-121.7 \mathrm{ppm} .{ }^{13} \mathrm{C} \mathrm{NMR}\left(\mathrm{CDCl}_{3}\right): 151.8(\mathrm{~d}, J=263 \mathrm{~Hz})$; $135.5(\mathrm{~d}, J=2 \mathrm{~Hz}) ; 132.4(\mathrm{~d}, J=5 \mathrm{~Hz}) ; 129.2(\mathrm{~d}, J=22 \mathrm{~Hz}) ; 126.7$ $(\mathrm{d}, J=8 \mathrm{~Hz}) ; 125.7(\mathrm{~d}, J=13 \mathrm{~Hz}) ; 124.7(\mathrm{~d}, J=4 \mathrm{~Hz}) ; 124.2(\mathrm{~d}, J=3$ $\mathrm{Hz}) ; 114.2(\mathrm{~d}, J=15 \mathrm{~Hz}) ; 31.5 ; 29.5 ; 29.2 ; 26.2 ; 22.5 ; 14.1 \mathrm{ppm}$. MALDI-TOF: 350.0770 . Anal. Calcd for $\mathrm{C}_{18} \mathrm{H}_{19} \mathrm{FS}_{3}$ : C, 61.67; H, 5.46; S, 27.44. Found: C, 61.27; H, 5.44; S, 27.48.

4'-Hexyl-5'-(thiophen-2-yl)-2,2':3',2'-terthiophene (10). 4 $(0.50 \mathrm{~g}, 1.23 \mathrm{mmol})$ and tributylstannylthiophene $(1.88 \mathrm{~g}, 5.03$ $\mathrm{mmol})$ were dissolved in dimethylformamide $(3 \mathrm{~mL})$. Argon was bubbled for $10 \mathrm{~min}$ into the solution. Then $\mathrm{Pd}\left(\mathrm{PPh}_{3}\right)_{4}(70 \mathrm{mg}, 0.06$ $\mathrm{mmol}$ ) was added and the solution was stirred for one night at $80^{\circ} \mathrm{C}$. A solution of $\mathrm{KF}(1 \mathrm{M}, 2 \mathrm{~mL})$ was added to the mixture, and the solution 
was stirred for $1 / 2 \mathrm{~h}$. Brine $(3 \mathrm{~mL})$ was added, and the mixture was extracted with ethyl acetate $(3 \times 10 \mathrm{~mL})$. The organic phases were dried over $\mathrm{MgSO}_{4}$ and evaporated. The crude product was chromatographed with a mixture of petroleum ether and $\mathrm{CH}_{2} \mathrm{Cl}_{2}(1 / 1)$ as eluent, and a pale yellow solid was obtained in $81 \%$ yield $(0.41 \mathrm{~g})$. Mp: $95{ }^{\circ} \mathrm{C} .{ }^{1} \mathrm{H}$ $\operatorname{NMR}\left(\mathrm{CDCl}_{3}\right): 7.50(\mathrm{dd}, 1 \mathrm{H}, J=1.1$ and $5.1 \mathrm{~Hz}) ; 7.37(\mathrm{dd}, 1 \mathrm{H}, J=1.1$ and $5.1 \mathrm{~Hz}) ; 7.23(\mathrm{dd}, 1 \mathrm{H}, J=1.1$ and $3.6 \mathrm{~Hz}) ; 7.17(\mathrm{~m}, 2 \mathrm{H}) ; 7.13(\mathrm{dd}$, $1 \mathrm{H}, J=3.6$ and $5.1 \mathrm{~Hz}) ; 7.06(\mathrm{~m}, 2 \mathrm{H}) ; 6.94(\mathrm{dd}, 1 \mathrm{H}, J=3.6$ and $5.1 \mathrm{~Hz})$; $2.64(\mathrm{~m}, 2 \mathrm{H}) ; 1.49(\mathrm{~m}, 2 \mathrm{H}) ; 7.21(\mathrm{~m}, 6 \mathrm{H}) ; 0.87(\mathrm{t}, 3 \mathrm{H}, J=6.5 \mathrm{~Hz}) .{ }^{13} \mathrm{C}$ NMR $\left(\mathrm{CDCl}_{3}\right): 141.1 ; 136.3 ; 135.9 ; 135.8 ; 134.7 ; 131.8 ; 129.1 ; 128.8$; 127.4 ; 127.2 ; $127.1 ; 126.8 ; 126.1 ; 125.9 ; 125.6 ; 31.2 ; 30.5 ; 29.2 ; 28.4$; 22.4; 14.0. IR $\left(\mathrm{cm}^{-1}\right): 3207,2925,1456,1220,693$. HRMS: calcd for $\mathrm{C}_{22} \mathrm{H}_{23} \mathrm{~S}_{4} 415.0677$, found 415.0676 .

\section{ASSOCIATED CONTENT}

\section{S Supporting Information}

Figure S1, presenting the CVs of 1 and 3, Figure S2, presenting the UV-vis absorption spectra of 3T-X, Figures S3-S5, presenting the CVs of $3 \mathrm{~T}-\mathrm{X}$, tables giving computational data for $3 \mathrm{~T}-\mathrm{X}$, and figures giving NMR spectra of $1-12,3 \mathrm{~T}-\mathrm{Br}$, and 3T-F. This material is available free of charge via the Internet at http://pubs.acs.org.

\section{AUTHOR INFORMATION}

\section{Corresponding Author}

*E-mail: pierre.frere@univ-angers.fr.

Notes

The authors declare no competing financial interest.

\section{REFERENCES}

(1) For reviews see: (a) Günes, S.; Neugebauer, H.; Sariciftci, N. S. Chem. Rev. 2007, 107, 1324. (b) Thompson, B. C.; Fréchet, J. M. J. Angew. Chem., Int. Ed. 2008, 47, 58. (c) Po, R.; Maggini, M.; Camaioni, N. J. Phys. Chem. C 2010, 114, 695. (d) Dennler, G.; Scharber, M. C.; Brabec, C. J. Adv. Mater. 2009, 21, 1323.

(2) Roncali, J. Macromol. Rapid Commun. 2007, 28, 1761.

(3) Roncali, J. Chem. Rev. 1997, 97, 173.

(4) (a) Chen, J. W.; Cao, Y. Acc. Chem. Res. 2009, 42, 1709. (b) Cheng,

Y.-J.; Yang, S.-H.; Hsu, C.-S. Chem. Rev. 2009, 109, 5868.

(5) Zhou, H.; Yang, L.; You, W. Macromolecules 2012, 45, 607.

(6) Scharber, M. C.; Mühlbacher, D.; Koppe, M.; Denk, P.; Waldauf, C.; Heeger, A. J.; Brabec, C. J. Adv. Mater. 2006, 18, 789.

(7) Soci, C.; Hwang, I. W.; Moses, D.; Zhu, Z.; Waller, D.; Gaudiana, R.; Brabec, C. J.; Heeger, A. J. Adv. Funct. Mater. 2007, 17, 632.

(8) (a) Li, G.; Shrotriya, V.; Huang, J. S.; Yao, Y.; Moriarty, T.; Emery, K.; Yang, Y. Nat. Mater. 2005, 4, 864. (b) Reyes-Reyes, M.; Kim, K.; Carroll, D. L. Appl. Phys. Lett. 2005, 87, 083506. (c) Reyes-Reyes, M.; Kim, K.; Dewald, J.; Lopez-Sandoval, R.; Avadhanula, A.; Curran, S.; Carroll, D. L. Org. Lett. 2005, 7, 5749. (d) Ma, W.; Yang, C.; Gong, X.; Lee, K.; Heeger, A. J. Adv. Funct. Mater. 2005, 15, 1617. (e) Ko, C.-J., K.; Lin, Y.-K.; Chun, F.-C.; Chu, C.-W. Appl. Phys. Lett. 2007, 90, 063509. (f) Kim, K.; Liu, J.; Namboothiry, M. A. G.; Carroll, D. L. Appl. Phys. Lett. 2007, 90, 163511. (g) Marrocchi, A.; Lanari, D.; Facchetti, A.; Vaccaro, L. Energy Environ. Sci. 2012, 5, 8457.

(9) (a) Peet, J.; Kim, J. Y.; Coates, N. E.; Ma, W. L.; Moses, D.; Heeger, A. J.; Bazan, G. C. Nat. Mater. 2007, 6, 497. (b) Park, S. H.; Roy, A.; Beaupre, S.; Cho, S.; Coates, N.; Moon, J. S.; Moses, D.; Leclerc, M.; Lee, K.; Heeger, A. J. Nat. Photon. 2009, 3, 297. (c) Chen, H. Y.; Hou, J. H.; Zhang, S. Q.; Liang, Y. Y.; Yang, G. W.; Yang, Y.; Yu, L. P.; Wu, Y.; Li, G. Nat. Photon. 2009, 3, 649. (d) He, Z.; Zhong, C.; Huang, X.; Wong, W.-Y.; Wu, H.; Chen, L.; Su, S.; Cao, Y. Adv. Mater. 2011, 23, 4636. (e) Dou, L. T.; You, J. B.; Yang, J.; Chen, C. C.; He, Y. J.; Murase, S.; Moriarty, T.; Emery, K.; Li, G.; Yang, Y. Nat. Photon. 2012, 6, 180.

(10) Chochos, C. L.; Economopoulos, S. P.; Deimede, V.; Gregoriou, V. G.; Lloyd, M. T.; Malliaras, G. G.; Kallitsis, J. K. J.Phys. Chem. C 2007, 111, 10732.

(11) Zhang, Q. T.; Tour, J. M. J. Am. Chem. Soc. 1998, 120, 5355.
(12) Reichenbacher, K.; Suss, H. I.; Hulliger, J. Chem. Soc. Rev. 2005, $34,22$.

(13) Babudri, F.; Farinola, G. M.; Naso, F.; Ragni, R. Chem. Commun. 2007, 1003.

(14) (a) Liang, Y.; Feng, D.; Wu, Y.; Tsai, S.-T.; Li, G.; Ray, C.; Yu, L. J. Am. Chem. Soc. 2009, 131, 7792. (b) Liang, Y.; Xu, Z.; Xia, J.; Tsai, S.-T.; Wu, Y.; Li, G.; Ray, C.; Yu, L. Adv. Mater. 2010, 22, E135. (c) Liang, Y.; Yu, L. Acc. Chem. Res. 2010, 43, 1227. (d) Son, H. J.; Wang, W.; Xu, T.; Liang, Y.; Wu, Y.; Li, G.; Yu, L. J. Am. Chem. Soc. 2011, 133, 1885. (e) Price, S. C.; Stuart, A. C.; Yang, L.; Zhou, H.; You, W. J. Am. Chem. Soc. 2011, 133, 4625.

(15) (a) Hergué, N.; Mallet, C.; Savitha, G.; Allain, M.; Frère, P.; Roncali, J. Org. Lett. 2011, 13, 1762. (b) Mallet, C.; Savitha, G.; Allain, M.; Kozmik, V.; Svoboda, J.; Frère, P.; Roncali, J. J. Org. Chem. 2012, 77, 2041. (c) Savitha, G.; Hergué, N.; Guilmet, E.; Allain, M.; Frère, P. Tetrahedron Lett. 201 1, 52, 1288. (d) Yassin, A.; Savitha, G.; Leriche, P.; Frère, P.; Roncali, J. New J. Chem. 2012, 36, 2412.

(16) Hergué, N.; Mallet, C.; Frère, P.; Allain, M.; Roncali, J. Macromolecules 2009, 42, 5593.

(17) Blanchard, P.; Verlhac, P.; Michaux, L.; Frère, P.; Roncali, J. Chem. Eur. J. 2006, 12, 1244.

(18) He, M.; Zhang, F. J. Org. Chem. 2007, 72, 442.

(19) Heeney, M.; Farrand, L.; Gilles, M.; Thompson, M.; Tierney, S.; Shkunov, M.; Sparrowe, D.; McCulloch, I. Eur. Pat. 1279690, 2003

(20) Doadt, E. G.; Snieckus, V. Tetrahedron Lett. 1985, 26.

(21) Sakamoto, Y.; Komatsu, S.; Suzuki, T. J. Am. Chem. Soc. 2001, 123, 4643.

(22) Frey, J.; Bond, A. D.; Holmes, A. B. Chem. Commun. 2002, 2424.

(23) Nicolas, Y.; Blanchard, P.; Roncali, J.; Allain, M.; Mercier, N.; Deman, A. L.; Tardy, J. Org. Lett. 2005, 7, 3513.

(24) The synthesis of compound 3T-H has been described in $40 \%$ yield by Kumada coupling: Chaloner, P. A.; Gunatunga, S. R.; Hitchcock, P. B. J. Chem. Soc., Perkin Trans. 2 1997, 1597.

(25) (a) Hergué, N.; Leriche, P.; Blanchard, P.; Allain, M.; GallegoPlanas, N.; Frère, P.; Roncali, J. New J. Chem. 2008, 32, 932. (b) Antolini, L.; Goldoni, F.; Iarossi, D.; Mucci, A.; Schenetti, L. J. Chem. Soc., Perkin Trans. 1 1997, 1957. (c) Casanovas, J.; Aradilla, D.; Poater, J.; Sola, M.; Estrany, F.; Aleman, C. Phys. Chem. Chem. Phys. 2012, 14, 10050.

(26) (a) Hansch, C.; Leo, A.; Taft, R. W. Chem. Rev. 1991, 91, 165. (b) Politzer, P.; Timberlake, J. W. J. Org. Chem. 1972, 37, 3557.

(27) Cardona, C. M.; Li, W.; Kaifer, A. E.; Stockdale, D.; Bazan, G. C. Adv. Mater. 2011, 23, 2367. 